\title{
Managerial Use of Discounted Cash-Flow or Accounting Performance Measures: Evidence from the U.K. Life Insurance Industry
}

\section{Paul J.M. Klumpes}

Tanaka Business School, Imperial College, London, South Kensington Campus, Exhibition Road, London SW7 2AZ, UK.

E-mail: Paul.Klumpes@imperial.ac.uk

Owing to the increasing prevalence of value-based methodologies and the competitive and political pressures faced by the industry to improve its performance, the U.K. life insurance industry provides an interesting environment in which to examine whether senior management uses accounting vs. projected cash-flow-based financial performance measures for both managerial performance evaluation and strategic budgetary planning and control purposes. A survey is employed to examine what economic and organizational factors could condition managerial propensity to use three alternative measures: traditional accounting-based measures, Economic Value Added (EVA) and multiperiod, actuarial cash flow based measures such as embedded value (EV). Survey evidence suggests that life insurance CEOs are more likely to use EV for strategic management planning and control purposes, and that this preference is strongly conditioned by the firm's ownership structure. These results support the managerial incentive hypothesis, after controlling for the effects of other organizational structural and behavioural variables that potentially influence the choice of financial performance measure.

The Geneva Papers (2005) 30, 171-186. doi:10.1057/palgrave.gpp.2510010

Keywords: embedded value; performance measure; accounting

\section{Introduction}

Rapid changes in the business environment have arisen as firms in general have faced pressures to replace traditional accounting-based measures such as Return on Capital Employed (ROCE) with new value-based performance measures that are claimed to represent more faithfully the "true economic performance" of the firm. One such measure, which has achieved widespread prominence, is economic value added $\left(E A^{\circledR}\right)$. As accounting-based measures typically focus on profits realized on existing business, they do not permit management to take credit for future profits that can be expected to be achieved on that block of business. In certain long-term contracting decision environments, the reliability of single-period accounting-based measures such as ROCE is therefore likely to be most problematic, both in capturing uncertain cash flows and by failing to incorporate an appropriate risk factor into the determination of the cost of capital to be allocated to the business line. This is particularly the case in life insurance, where long operating cycles cause conventional accounting-based measures to be particularly poor indicators of periodic business performance. 
In a typical life insurance contract, a customer pays a cash premium to the life insurer in return for a contract promising a stream of state-contingent cash payments in the future. Issuing this contract creates a liability for the life insurers, the vast bulk of which is held by their customers rather than their investors. ${ }^{1}$ Thus, a major problem facing life insurance firm CEOs is how to plan and control this stream of contracts emerging over time. Cash-flow projection-based performance measures are likely to be especially appropriate to industry settings where CEOs manage contingent forms of contracts that are subject to long-term and uncertain cash flows. In such industries, calculations of "economic value" or "present value of future cash flow" for use in performance measurement are often proposed by consultancy professionals, who claim to possess superior knowledge about the industry. During the 1990s, industry professionals developed embedded value (EV), defined as changes in the value of a block of multiperiod insurance, banking or investment business projected into the future, and then discounted to the present using a risk-adjusted discount rate. However, EV also requires subjective managerial assumptions to be made concerning growth rates, interest rates that are sensitive to changing business and economic circumstances. ${ }^{2}$

The U.K. life insurance industry is currently the largest in Europe and the third largest in the world. ${ }^{3}$ It therefore provides an interesting environment in which to examine the managerial use of alternative performance measures for a number of reasons. First, the availability of competing (accounting vs. expected future cash flow) approaches towards assessing managerial performance is generally well known and well understood by most U.K. industry CEOs. ${ }^{4}$ Secondly, the choice of measure may impinge on observed performance and disclosure incentives, since the industry has recently faced competitive, consumer and political pressures to improve its managerial efficiency. ${ }^{5}$ Thirdly, the industry has evolved separate performance measurement bases for shareholder reporting (EV) and in order to meet conservative regulatory solvency rules (based on ROCE). However recent corporate governance crises at two major U.K. mutual firms (Equitable Life and Standard Life) has led to public criticism over the adequacy of their financial management practices. Finally, the new International

\footnotetext{
${ }^{1}$ Mayers and Smith (1981); Fama and Jensen (1983).

${ }^{2}$ In 1998, the Association of British Industry developed a draft Statement of Recommended Practice (SORP) for general financial reporting purposes based on EV. However, in 2002, both the U.K.'s Accounting Standards Board and the International Accounting Standards Board decided not to adopt the draft SORP as a basis for developing an industry-specific financial reporting standard, apparently due to concerns over managerial discretion over estimating the "fair value" of insurance business (see also Accounting Standards Board, 2003). An EV Principles paper issued by the CFOs of major European insurance companies has since documented the practice (CFO Forum, 2004). However, EV was not codified or endorsed as best practice reporting by the Accounting Standards Board (2004), which instead in July 2004 issued an exposure draft (FRED 34 - Life Insurance) for financial reporting that proposed the realistic calculation of liabilities to be incorporated in the financial statements for December 2004 year end onwards. A new disclosure, the capital position statement, will provide significantly improved information about restrictions on the use of capital of a life assurer.

${ }^{3}$ Tillinghast (2004).

${ }^{4}$ Macve and Wild (1999).

${ }^{5}$ Klumpes (2002).
} 
Financial Reporting Standard No. 4, issued in March 2004, requires the eventual adoption of a asset-liability framework for reporting performance of life insurance contracts. However, the Geneva Association's Accountancy Taskforce reported a survey that found that no major international insurance company "currently uses a full fair value system as a general accounting model for internal planning and control, nor would any company wish to do so voluntarily". ${ }^{6}$ This highlights the importance of evidence as to what performance measures are currently being used by the industry.

The purpose of this paper is to examine these issues in an intra-industry context. We examine cross-sectional variation in the use of (ROCE, EVA vs. EV) performance measure by U.K. life insurance firm CEOs for performance strategic planning and control purposes. It is predicted that the choice of measure is likely to interact with its preferred choice of management control structure. Evidence favouring such associations would support the empirical implications of the positive theory of insurance contracting. The managerial discretion hypothesis implies that life insurance CEOs choose discounted cash-flow-based performance measures, since they better associate with their management control structure. ${ }^{7}$

This paper provides empirical evidence on whether U.K. life insurance firm CEOs' use of performance measures for management planning and control is consistent with the managerial incentive hypothesis. It reports the results of a survey sent to a sample of 35 financial controllers of life insurance firms, about the perceived usefulness of these alternative measures for both management planning and control purposes. The results suggest that firms' ownership structure significantly affects managerial preferences for the use of traditional vs. more sophisticated value-based financial performance measures. Most significantly, CEOs of stock firms are more likely to use financial performance measures that involve cash-flow projections (such as EV) for strategic budgeting and planning purposes than are CEOs of mutual firms. These results are robust. They hold after the survey was repeated following a period of extensive industry consultation, and after controlling for other variables capturing various financial and organizational characteristics of life insurance firms.

The rest of this paper is organized as follows. The next section defines reviews of prior research. The subsequent section derives the testable hypotheses and the section thereafter reports the empirical results of the survey. The last section provides a conclusion.

\section{Prior research}

This section provides the background needed to understand financial performance measurement in the U.K. life insurance industry. The following subsection overviews related prior research while the subsequent subsection provides the institutional background.

\footnotetext{
${ }^{6}$ Dickinson and Liedtke (2004, p. 69).

${ }^{7}$ Mayers and Smith (1981, p. 144).
} 


\section{Review of prior research}

A considerable body of prior literature has examined the consequences and antecedents of the reliance on accounting performance measures for management planning and control in other (non-insurance) contexts. This literature has examined alternative styles used by CEOs to hold subordinates accountable for their performance. ${ }^{8}$ However, Otley and Fakiolas ${ }^{9}$ question the role of accounting-based performance measurement techniques, and claim that their role, both in controlling operations and in monitoring overall organizational and managerial performance, is being superseded by value-based concepts (such as EV).

Biddle et al. ${ }^{10}$ examine the information content of EVA vs. ROCE in terms of their association with share prices. This research implies that accounting-based performance measures are more value-relevant than value-based measures. Wallace ${ }^{11}$ finds that CEOs make decisions consistent with the incentives of the new residual incomebased measures. However, prior studies neither predict which firms are likely to adopt discounted cash flow measures nor examine whether these measures are preferred by CEOs for decision-making over the traditional accounting measures.

Prior empirical evidence indicates that there is considerable cross-sectional variation in the propensity of CEOs to use accounting and cash-flow performance measures across the U.K. life insurance industry. Klumpes ${ }^{12}$ finds that the propensity of Australian and U.K. life insurance firm CEOs to voluntarily use actuarial income smoothing rather than accounting-based profits in their annual reports is positively associated with both the level of information asymmetry, mutual status, size and solvency. However, to date, no research has examined specifically whether managerial use of alternative performance measures is associated with the financial management and control structures of these financial institutions.

Mayers and Smith ${ }^{13}$ provide an alternative theoretical justification for managerial incentives to use performance measures in costly contracting environments such as life insurance. They develop a positive theory of insurance contracting, which suggests that managerial discretionary decision-making and delegated control is related to a number of organizational variables, such as ownership and marketing distribution systems. Evidence from managerial discretion over brochures offering investmentrelated Australian life insurance products ${ }^{14}$ and the balance-sheet structure of New Zealand life insurance firms ${ }^{15}$ supports this hypothesis. Since life insurance contracting

\footnotetext{
${ }^{8}$ Hopwood (1972); Otley (1978). These styles depend upon both the extent and manner in which budgetary information is used. Under a budget-constrained style of performance evaluation, budgetary information forms a central part of the evaluation and so success in meeting budget targets is judged as the primary criterion for assessing performance. By contrast, under a profit-conscious style, budgetary information is used in a more flexible manner and is seen as just one indicator of longer-term concern with costs.

${ }^{9}$ Otley and Fakiolas (2000).

${ }^{10}$ Biddle et al. (1997).

${ }^{11}$ Wallace (1997).

${ }^{12}$ Klumpes (2002).

13 Mayers and Smith (1981).

${ }^{14}$ Klumpes (1995).

15 Adams (1995).
} 
is costly, we expect that the choice of alternative measures of life insurance firms are associated with the choice of managerial ownership, and the propensity of CEOs to use alternative methods for both management planning and performance management is associated with these variables.

The choice of performance measure is also expected to interact with evaluation style and management control structure. These styles depend upon both the extent and manner in which budgetary information is used. Under a budget-constrained style, budgetary information forms a central part of the evaluation project and so success in meeting budget targets is the primary criterion for performance. By contrast, under a profit-conscious style, budgetary information is used in a more flexible manner and is seen as just one indicator of longer-term concerns with costs. However Otley and Fakiolas ${ }^{16}$ question the role of accounting-based performance measurement techniques and claim that their role both in controlling operations and in monitoring overall organizational and managerial performance is being superseded by value-based concepts (such as activity-based costing). They also claim that the development of market-orientated performance measures, such as EV, question the reliability of accounting-based financial planning. This criticism is particularly relevant to understanding the performance management of financial service firms, which have long-term uncertain contracts combined with a historical lack of familiarity with standard corporate profit-based accounting measures.

\section{An institutional setting}

In the U.K. and many British Commonwealth countries, the life insurance industry has been heavily regulated, and the financial management and control of the industry has been traditionally dominated by actuaries rather than accountants. Historically, life insurance firms in these countries have produced financial reports that were oriented towards meeting regulatory-imposed solvency requirements, rather than profit reporting. ${ }^{17}$ However, in the early 1990s, pressures for direct competition with other financial service providers, de-regulation and capital raising led to the development of competing (accounting vs. actuarial) profit reporting standards in Australia $^{18}$ and the U.K. ${ }^{19}$

In recent years, the U.K. life insurance industry has been confronted with a more uncertain and rapidly changing business environment. Firms have had to cope with intense product competition from other financial service firms, technological innovation in distribution channels and a widespread loss of trust from customers resulting from the apparent mis-selling of personal pensions. These pressures have imposed new capital strains on many firms and have led to an increasingly rapid consolidation of the U.K. life insurance industry. They have also resulted in demands for new financial performance measures that more reliably capture the long-term value

\footnotetext{
${ }^{16}$ Otley and Fakiolas (2000).

${ }^{17}$ Horton and Macve (1995).

18 Klumpes (1995).

${ }^{19}$ Horton and Macve (1995); Klumpes (1999).
} 
of life insurance firm business. The U.K. financial press has alleged that the failure of The Equitable to meet its obligations to annuity holders is at least partly due to the failure of traditional accounting to evaluate management performance. ${ }^{20}$ More recently, the apparent insolvency of a number of life insurance firms has highlighted apparent abuses in accounting practices used for regulatory solvency. ${ }^{21}$

Recently, the International Accounting Standards Board has proposed replacing existing GAAP as a basis for financial reporting with a more direct, discounted cashflow-based measure of life insurance firm reporting that is based on explicit "fair" valuation of the business. Currently, there is some controversy among accounting and actuarial professionals about what method is most reliable for measuring the financial performance of life insurance firms. EVA is a special case of a measure known as "residual income", which has a long pedigree in the management control literature. Partly because of the formal links between economic value, accounting book value and the present value of expected future residual income, it is argued that EVA forms a sound basis for the promotion of value-maximizing behaviour by corporate CEOs. ${ }^{22}$

By contrast, EV impounds estimates of the present value of future profits on existing long-term life insurance business. Actuaries claim that this method is appropriate for the management control of life insurance firms. ${ }^{23}$ For example, in discussing how company executives should measure the profitability of their life insurance business, Mehta $^{24}$ argues that accounting measures of profit incorporate numerous artificial and subjective elements and fail to account adequately for risk and the time value of money. He proposes an alternative EV-based definition of profit that is claimed to lead to consistency between profit and value maximization, and is in accord with "general principles of modern financial theory".

Thus, in linking the various performance measures to an ideal construct of the abnormal change in the economic value of the business, accounting profit (or ROCE) is the least complete in that it omits consideration of the cost of capital relating to the net assets recognized in the balance sheet and ignores changes in value that are not captured by standard accounting practice. ${ }^{25}$ EVARI is more complete than accounting profit (or ROCE) in that it takes account of the cost of capital relating to the net assets recognized in the balance sheet, although it ignores changes that are not captured by the accounting system (or by the adjusted accounting system in the case of EVA). EV profit is also more complete than accounting profit (or ROCE) in that it captures some changes in the economic value of the business that are not captured by standard accounting practice, although it does not include a capital charge. EVARI and EV

${ }^{20}$ Financial Times (27 September 2001).

${ }^{21}$ The Economist (5 August 2002). The accounting and EV measures are discussed in more detail by Klumpes (1999). The discussion of EVA is based on the discussion in O'Hanlon and Peasnell (1998).

${ }^{22}$ Lee (1999).

${ }^{23}$ O'Brien (1994).

${ }^{24}$ Mehta (1996).

${ }^{25}$ The Statutory Solvency Method outlined in this section was subsequently replaced by the "modified statutory solvency method" for the purposes of compliance with an Insurance Accounts Directive issued by the European Union, effective in 1995. 
each move part of the way from accounting profit (or ROCE) towards a fuller representation of the abnormal periodic change in the economic value of the business.

\section{Use of performance measures in practice}

In this section, we develop predictions about the empirical associations between the choice of performance measure and various organizational structure characteristics of life insurance firms that may influence CEOs' financial management decisions. Since life insurance contracting is a costly activity, we examine whether the choice of alternative performance measures by life insurance firm CEOs is dominated by the firm's choice of managerial ownership, or by the internal culture as revealed by the management control system structures. These relationships are discussed below with hypotheses outlined subsequently.

\section{Ownership structure, firm characteristics and choice of performance measure}

Life insurance firms possess important distinguishing features that make their financial performance particularly amenable to more sophisticated EV analysis. First, at an operational level, they specialize in insuring unique and non-diversifiable risks, which require costly control mechanisms that can significantly reduce the profits arising from existing business. Secondly, senior management also requires information about the present value of their existing business in the future, based on the cash-flow relationship of their assets and liabilities, based on actuarial assessments of mortality and investment risk.

However, the existence of both stock and mutual companies in the life insurance industry has important implications for understanding the nature of management control and the associated managerial discretion over performance measurement. ${ }^{26}$ In a mutual company, ownership rights are not transferable because they are not separable from the policyholders' insurance policies. This inalienability has important implications for the technology of management control, and reinforces the importance of managerial monitoring systems, including accounting control. However, mutuality also poses conceptual difficulties in determining periodic "profit" in a sophisticated sense, and thus mitigates against the application of complex actuarial calculations of "economic profit", defined as the change in value of the entity over time. This suggests that CEOs of stock firms have a greater propensity to use value-based or actuarialbased performance measures than do CEOs of mutual life insurance firms. There is evidence that these performance measures may serve different purposes for stock and mutual life insurance firms operating in Australia and in the U.K.

\footnotetext{
${ }^{26}$ Mayers and Smith (1981) develop a positive theory of insurance contracting which suggests that managerial discretionary decision-making and delegated control is related to a number of organizational variables, such as ownership and marketing distribution systems. Evidence from both Australian life insurance managerial discretion over brochures offering investment-related life insurance products (Klumpes, 1995) and balance-sheet structure of New Zealand life insurance firms (Adams, 1995) supports this hypothesis.
} 
This prediction appears to be corroborated by evidence presented by Klumpes ${ }^{27}$ on the different explanations for the propensity of stock and mutual U.K. life insurers to voluntarily report EV in their annual reports. Klumpes ${ }^{28}$ investigates incentives facing CEOs of 67 Australian and U.K. life insurers to voluntarily report EV information in their annual reports during the period 1991-1995. He finds EV-adoption by stock firms is related to a desire to improve the efficiency of information sent to capital market participants, while mutual firms appear to do so for earnings management purposes.

\section{Development of hypotheses}

The above section suggests that the choice of performance measurement is associated with firms' ownership, distribution and international business organizational characteristics, which that tend to dominate the structure of today's U.K. life insurance industry. A number of management control factors may also influence CEOs' discretion over the choice of method. In this section we separately consider the decision to use performance measures for strategic planning and control (PERFPC). This distinction is important since prior literature suggests that flexibility provided by measures such as EV, in allowing CEOs to choose an appropriate discount rate for determining the cost of capital, may be important for planning and control purposes. ${ }^{29}$

For planning and control purposes, it is predicted that the choice of performance measure is associated with the existence of a budget-constrained style of performance evaluation. As discussed in the second section of the paper, prior empirical research has found that firms that rely on accounting-based measures of performance use a budget-constrained style of performance evaluation..$^{30}$ By contrast, firms that rely on non-accounting-based measures such as value-based performance criteria tend to use a profit-conscious or non-accounting style of performance evaluation. We hypothesize that there will be a positive association between the propensity of management to use non-accounting-based performance measures and the decision to use a non-accounting style of planning and control (NAPE).

Other factors that affect managerial discretion over choice of performance measures for strategic planning and control purposes include the complexity and ownership structure of life insurance business. We use two proxies for these variables: the extent of international diversification (INTLD) and whether the firm is mutual or stock owned $(O W N E R)$. Formally, our hypothesized relationship between performance measures for strategic planning and control purposes (PERFPC) and these variables is as follows:

$$
P E R F P C=f(O W N E R, N A P E, I N T L D)
$$

\footnotetext{
${ }^{27}$ Klumpes (2002).

${ }^{28}$ Ibid.

${ }^{29}$ O'Brien (1994).

${ }^{30}$ Otley (1978).
} 


\section{Empirical tests}

This section describes the sample selection procedures and research instrument used to administer the survey. We then report the results of empirical tests on the predicted association between choice of ownership structure and performance measure. Finally, we discuss the reasonableness of our empirical results with comments received directly from CEOs who participated in the survey.

\section{Sample selection and survey}

The chief financial executives of the top 50 U.K.-based life insurance companies were asked to participate in a survey about the factors influencing their choice of performance measures for strategic planning and control and managerial evaluation purposes. These firms were randomly selected from a larger subpopulation of approximately 120 U.K. life insurance companies for which data are regularly reported by the UNIC database on the grounds that they have demonstrated a continuous record of operating in the life insurance industry over the decade 1990-1999. This period represented a period of significant political and economic uncertainty that affected the operation of the U.K. life insurance industry during which a number of alternative actuarial and accounting-based performance measures were proposed for financial accounting, management accounting and valuation purposes. Firms were initially given four weeks to reply and could elect to return their responses anonymously. A further letter was sent after this period which provided non-responding firms a further four weeks to respond.

The survey letter was accompanied by a questionnaire that was to be completed and returned by reply-paid envelope. A copy of the questionnaire is reproduced in the Appendix. The questionnaire contained:

(i) a question requesting information concerning the organizational characteristics of the company (ownership structure, assets under management; dominant distribution channel; dominant line of business; extent of non-U.K. business, and number of business lines);

(ii) one question on a description of the company's management structure, in terms of the budgetary planning process (budget-constrained or profitconscious); product level financial accountability structure (centralized or decentralized); and performance standards (internal variance vs. external benchmarking);

(iii) two questions that asked respondents to describe whether EVA, ROCE, EV or another (to be specified) financial performance measure was considered to be most relevant to both (a) strategic budgetary planning and control processes; and (b) for evaluating the performance of line management; and

(iv) an open-ended question asking respondents to comment on the perceived decision-usefulness or otherwise of these alternative performance measures for both operational and strategic management planning and control. This provided a means of verifying the reliability of the closed questions asked in (ii) and (iii) above. 
A total of 35 U.K.-based firms (70 per cent) agreed to participate in the survey. ${ }^{31}$ The high response rate reflects the topical nature of the performance measurement issue in the life insurance industry, and suggests that most CEOs fully comprehended the issues raised by the questionnaire. Steps were taken to verify the identity of those who completed the questionnaire by requesting a copy of the respondents' business card. In all cases, either the chief financial officer or finance director returned his or her business card.

\section{Descriptive statistics and univariate tests}

The data variables are described below:

PERFPC A dummy variable indicating the performance measure used for planning and control. Accounting $(=0)$ vs. non-accounting $(=1)$ performance measures.

OWNER A dummy variable indicating whether the firm was mutual (coded 0) or stock (coded 1).

NAPE A dummy variable indicating whether the firm used a budgetconstrained (coded 0 ) or profit-conscious (coded 1) style of performance evaluation.

INTLD A dummy variable indicating whether more than 10 per cent of total life insurance business was conducted outside the U.K. (coded 1) or not (coded 0$)$.

Table 1 reports, for the sample of 35 U.K. firms, univariate Mann-Whitney $U$-tests of the differences between firms using accounting performance measures from those using non-accounting performance measures for both planning and control, and for performance evaluation purposes. For planning and control, only $O W N E R$ is statistically significant at the 10 per cent level, while for performance evaluation, only DISTN is significant at the 10 per cent level. These unsophisticated tests tentatively suggest that the propensity to use accounting-based performance measures is a result of conditioned organizational characteristics, but that these differ depending on the purpose served.

\section{Multivariate tests}

A multivariate test allows for correlations among the explanatory variables and provides a method for determining the incremental effect of each variable and the overall explanatory power of all variables. Table 2 reports bivariate Pearson's correlations between each of the descriptive variables. None of these correlations are statistically significant at the 1 per cent level.

Logistic regression tests of the PERFPC model are reported in Table 3, in Panels A and $\mathrm{B}$, respectively. These results are fully consistent with the univariate tests reported in Table 1. For the PERFPC model, both INTLD and NAPE are in the predicted

\footnotetext{
${ }^{31}$ Standard tests were conducted to examine the impact of possible non-response bias. However, there were no distinguishing differences between early and late responding firms.
} 
Table 1 Univariate tests of association between propensity to use accounting $(=0)$ vs. non-accounting $(=1)$ performance measures and organizational characteristics $(n=35)$

\begin{tabular}{lc}
\hline Sample & Mann-Whitney \\
\hline OWNER & U-test: Z-statistic \\
NAPE & $-2.502^{*}$ \\
INTLD & -0.582 \\
\hline
\end{tabular}

$O W N E R=$ A dummy variable indicating whether the firm was mutual (coded 0) or stock (coded 1).

$N A P E=$ A dummy variable indicating whether the firm used a budget-constrained (coded 0 ) or profitconscious (coded 1) style of performance evaluation.

$I N T L D=$ A dummy variable indicating whether more than $10 \%$ of total life insurance business was conducted outside the U.K./Australia (coded 1) or not (coded 0).

*Statistically significant at $1 \%$ level.

Table 2 Correlation among explanatory variables $(n=35)$

\begin{tabular}{lccc}
\hline & OWNER & NAPE & INTLD \\
\hline OWNER & 1.000 & - & - \\
NAPE & 0.023 & 1.000 & - \\
INTLD & -0.082 & $-0.320^{*}$ & 1.000 \\
\hline
\end{tabular}

$O W N E R=$ A dummy variable indicating whether the firm was mutual (coded 0$)$ or stock (coded 1). $N A P E=$ A dummy variable indicating whether the firm used a budget-constrained (coded 0$)$ or profitconscious (coded 1) style of performance evaluation.

$I N T L D=$ A dummy variable indicating whether or not more than $10 \%$ of total life insurance business was conducted outside the UK/Australia (coded 1) or not (coded 0 ).

*Statistically significant at $10 \%$ level.

Table 3 Logistic regression of decision to use accounting- vs. non-accounting-based performance measures $(\mathrm{n}=35)$

Number of observations $=35$

Dependent variable PERFPC

$=0$, if using accounting performance measure $(n=17)$

$=1$, if using non-accounting performance measure $(n=18)$

Estimating model: PERFPC $_{\mathrm{i}}$

$=\alpha_{0}+\mathrm{B}_{1} \mathrm{OWNER}_{i}+\mathrm{B}_{2} \mathrm{NAPE}_{i}+\mathrm{B}_{3} \mathrm{INTLD} i+\varepsilon$

Intercept
OWNER

NAPE

0.014

0.384

\begin{tabular}{lcccc}
\hline Expected Sign & $?$ & + & + & + \\
Coefficient & -1.759 & 1.987 & $(0.832)$ & 0.7250 .961 \\
Std Error & $(0.924)$ & $(0.810)$ & 0.384 & $0.990)$ \\
Significance & 0.057 & 0.014 & $\chi^{2}$ statistic: $8.010(P=0.046)$ & 0.332 \\
\end{tabular}

INTLD

$O W N E R=$ A dummy variable indicating whether the firm was mutual (coded 0) or stock (coded 1). $D I S T N=$ A dummy variable indicating whether the firms' distribution system involved tied or representative sales agents (coded 0) or independent financial advisers (coded 1).

$N A P E=$ A dummy variable indicating whether the firm used a budget-constrained (coded 0 ) or profitconscious (coded 1) style of performance evaluation.

$I N T L D=$ A dummy variable indicating whether more than $10 \%$ of total life insurance business was conducted outside the U.K./Australia (coded 1) or not (coded 0). 
direction, but are not statistically significant. $O W N E R$ is statistically significant and in the predicted direction. The overall model $\chi^{2}$ statistic is again significant at the 5 per cent level. These results imply that, even after controlling for variables representing other firm characteristics, mutual life insurance firms are more likely to use accounting-based performance measures for management planning and control purposes than are stock firms.

\section{Discussion of results}

To check the robustness of our main empirical findings, we also asked CEOs who participated in the survey to provide reasons for their preferred performance measure. Approximately two-thirds of the respondents listed various justifications for their choices. Their comments shed further light on the decision-usefulness of the various measures to particular firm CEOs and generally corroborated the empirical results reported above.

EV was often cited by stock firm CEOs as providing guidance in the management of profits emerging to shareholders. On the other hand, some proponents of EVA admitted that EV is not easily analysed in sufficient detail for a "real understanding of business performance at an operational level".

Proponents of accounting-based measures appeared less convinced about their perceived decision-usefulness. One manager claimed that "simple, profit-based measures" are most useful. However, a number of CEOs listed EVA or ROCE only because they were "told to do so" by their parent firm, and did not find them to be particularly useful to their strategic or operational decisions. Another manager admitted that EVA was "neither well understood nor easy to communicate to lower levels".

These results confirm our main empirical findings that both strategic and organizational factors tend to condition the perceived usefulness of both accounting-based as well as EVA and EV measures in the financial management of the U.K. life insurance industry. It is also interesting to observe that none of the respondents claimed to be using non-financial performance measures, or multiattribute performance measures such as the balanced scorecard. This finding, while restricted to CEOs of the top 50 U.K. life insurance firms, contradicts claims made by earlier researchers that the use of non-financial performance measures ${ }^{32}$ and the balanced scorecard ${ }^{33}$ are becoming more popular tools to evaluate and motivate managerial performance, even among British firms. ${ }^{34}$

\section{Follow-up survey}

The U.K. life insurance industry has been subject to significant consolidation and rationalization in recent years. Since the original survey was conducted in 1997, a

\footnotetext{
${ }^{32}$ Ittner et al. (1997).

33 Silk (1998).

${ }^{34}$ Rees and Sutcliffe (1994).
} 
number of mutual life insurance companies have either demutualized (e.g. NPI), have been taken over by stock companies (e.g. Scottish Widows) or stopped actively selling new business altogether (e.g. The Equitable). To ensure the robustness of these results over time to changes in the structure of the U.K. life insurance industry, a follow-up survey was repeated on the same initial sample of firms five years after the initial survey work was completed (i.e. in 2002). It should be noted that 18 out of the 50 original total sample companies were no longer in existence as a result of takeovers, mergers or companies withdrawing from the industry: many of the affected companies were mutuals. This is consistent with the overall industry trend for the same period. The survey questionnaire was identical to the original survey and the same administration procedures were used. A total of 16 companies responded (a 50 per cent response rate), of which 13 were stock companies and three were mutuals. The analysis yielded substantially the same results as for the initial survey; there is evidence that an increasing number of companies are continuing to use embedded value for performance evaluation and managerial planning and control. This result is consistent with recent survey evidence conducted by PriceWaterhouseCoopers (2003) that insurance firms are mostly concerned with the information gap between "share value" and "fundamental value". However, it is not consistent with the apparent lack of any endorsement of EV for reporting purposes by the IASB's FRS 4.

\section{Conclusion}

The financial management literature is replete with assertions that discounted cash-flow- and value-based methodologies are increasingly being relied upon by corporate CEOs for decision-making purposes. This study examines the conceptual arguments advanced in support of both discounted cash-flow- and value-based performance measures, and empirically examines their relevance to the financial management decisions made by CEOs of U.K. life insurance firms. The U.K. life insurance industry provides an interesting environment in which to examine these issues because of the prevalence of value-based methodologies and the competitive and political pressures faced by the industry to improve its performance. Our survey also provides empirical evidence about the propensity of CEOs to use these alternative methods for strategic planning and control purposes. Consistent with prior theory, it is assumed that the choice of performance measurement by life insurance firm CEOs is associated with their discretion over ownership and management control structures.

The major conceptual differences between both traditional accounting-based measures, and value-based measures such as EVA and EV suggest that the former category utilizes well-established accounting concepts of income whereas the latter relies on closer approximations to abnormal economic income. These differences are important because only stock firms can fully benefit from utilizing the more sophisticated, value-based measures for management control purposes. These theoretical predictions are supported by the empirical results, which suggest that the choice of sophisticated cash-flow performance measures for management planning and control purposes by U.K. life insurance CEOs is strongly associated with the 
choice of ownership structure. These results hold even after controlling for the effects of other organizational structural variables that potentially influence managerial performance and control.

Our findings thus corroborate and extend those of earlier researchers about the reliance on accounting performance measures and the role of accounting as an important mechanism in the management control of life insurance firms. The results are further corroborated by a subsequent follow-up survey of the same companies. However, these findings should be treated with caution, given the move away from mutual status by the U.K. insurance industry in recent years, and the growing likely importance of fair value (market value margin) reporting to comply with new international accounting standards.

These important caveats notwithstanding, the empirical results imply that CEOs of stock-based life insurance firms are faced with greater incentives to use discounted cash-flow measures that are likely to interact with their investment, marketing and distribution structures. By providing direct evidence on the discounted cash-flowbased performance measures in an intra-industry setting, these findings extend those of earlier empirical research that examines the reliability of accounting performance measures and the role of residual income as an important mechanism in the management control of life insurance firms.

However, there are important limitations to the scope of these implications. First, the competition and regulatory changes over the study period effectively reduce the explanatory power of contracting-related variables that we posit to be associated with managerial choice over performance measurement, ownership, marketing and accounting control structures. Secondly, the small sample size, together with the need to anonymize the responses, potentially limits the validity of the statistical analysis, since exact data on firm size and other characteristics are not available. Finally, the follow-up survey revealed a decline in the number of mutual companies, which may suggest that the role of accounting measures by CEOs in the industry as a whole is becoming even less prevalent over time. Subject to these caveats, the results suggest that management discretion between accounting and discounted cash-flow performance measures are important attributes of the financial management of U.K. life insurance firms.

\section{Acknowledgements}

Financial assistance for this research was provided by a CIMA research grant. We thank participants at an accounting workshop at the University of Warwick and at the Vrije Universiteit, Amsterdam, for comments provided on an earlier version of this paper.

\section{References}

Accounting Standards Board (2003) Consultation Paper on Insurance Contracts, London: Accounting Standards Board.

Accounting Standards Board (2004) Financial Reporting Exposure Draft 34: Life Insurance, London: Accounting Standards Board.

Adams, M. (1995) 'The balance sheet structure of the New Zealand Life insurance industry: A test of the managerial discretion hypothesis', Accounting and Finance 20: 23-54. 
Biddle, G.C., Robert, M., Bowen, R.M. and Wallace, J.S. (1997) 'Does EVA ${ }^{\circledR}$ beat earnings? Evidence on associations with stock returns and firm values', Journal of Accounting and Economics 24(3): 301-336.

CFO Forum (2004) European Embedded Value Principles.

Dickinson, G. and Liedtke, P.M. (2004) 'Impact of a fair value reporting system on insurance companies: A survey', The Geneva Papers on Risk and Insurance: Issues and Practice - Special issue 29(3): 1-20.

Fama, E. and Jensen, M. (1983) 'Agency problems and residual claims', Journal of Financial Economics 26: 327-348.

Hopwood, A. (1972) 'An empirical study of the role of accounting data in performance evaluation', Journal of Accounting Research (Supplement) 10: 156-182.

Horton, J. and Macve, R. (1995) Life Insurance Accounting in the U.K.: A True and Fair View?, London: ICAEW.

Ittner, C., Larcker, D. and Rajan, M. (1997) 'The choice of performance measures in annual bonus contracts', The Accounting Review 72: 231-255.

Klumpes, P. (1995) 'Voluntary disclosure by financial intermediaries: Evidence from Australian life insurers offering investment related contracts', Accounting and Finance 35: 21-46.

Klumpes, P. (1999) 'Measuring the profitability of stock life insurers', British Accounting Review 31: 185-204.

Klumpes, P. (2002) 'Incentives facing life insurance firms to report actuarial earnings: Evidence from Australia and UK', Journal of Accounting, Auditing and Finance 17(3): 237-258.

Lee, C.M.C. (1999) 'Accounting-based valuation: impact on business practices and research', Accounting Horizons 13(4): 413-425.

Macve, R. and Wild, K. (1989) 'Accountants vs. Actuaries', Accountancy (Dec): 78-90.

Mayers, D. and Smith, C. (1981) 'Contractual provisions, organizational structure, and conflict control in insurance markets', Journal of Business 54(3): 407-434.

Mehta, S. (1996) Quantifying the success of a life office, paper presented at the Staple Inn Actuarial Society.

O'Brien, C. (1994) 'Profit, capital and value in a stock life assurance company', Journal of the Institute of Actuaries 121: 285-361.

O'Hanlon, J. and Peasnell, K. (1998) 'Wall street's contribution to management accounting: The Stern Stewart EVA Financial Management System', Management Accounting Research.

Otley, D.T. (1978) 'Budget use and managerial performance', Journal of Accounting Research (Spring) 18: $122-149$.

Otley, D.T. and Fakiolas, M. (2000) 'Reliance on accounting performance measures: Dead end or new beginning?', Accounting, Organizations and Society 25(4): 497-510.

PriceWaterhouseCoopers (2003) Value Added Reporting: A Survey of the International Insurance Industry, London: PriceWaterhouseCoopers.

Rees, W. and Sutcliffe, C. (1994) 'Quantitative nonfinancial information and income measures: the case of long term contracts', Journal of Business Finance and Accounting (April) 21: 331-347.

Silk, S. (1998) 'Automating the balanced scorecard', Management Accounting (May): 38-44.

Tillinghast (2004) Insurance Fact Book 2004, London: Tillinghast.

Wallace (1997) 'Adopting residual-income based compensation plans - do you get what you pay for?', Journal of Accounting and Economics 24(3): 275-300.

\section{Appendix}

\section{SURVEY QUESTIONNAIRE}

The Use of Alternative Performance Measures for Managerial Performance in the U.K. Life Insurance Industry

1. Please describe your firm's organizational characteristics (select one):

- ownership structure (mutual or stock)

- $\quad$ total business assets ( $>£ 500 \mathrm{~m}$ or less than $£ 500 \mathrm{~m}$ )

- dominant distribution channel (direct sales or independent advisers) 
- dominant business channel (life/non-life)

- extent of non-U.K. business ( $>10 \%$ or less than $10 \%$ of total business)

- number of business lines ( $>5$ or more or $<5$ actively sold)

2. Please describe your firm's management control structure (select one):

- budgetary planning process (budget-constrained or profit conscious)

- $\quad$ product-level financial accountability structure (centralized or decentralized)

- dominant performance standard (internal variances or external benchmarking)

3. Please describe which of the following performance measures is the most relevant to your firm's strategic budgetary planning and control processes (tick ONLY one of the following):

- $\quad$ economic value-added $\left(\mathrm{EVA}^{\circledR}\right)$

- return on capital employed (ROCE)

- residual income

- embedded value

- other (please specify)

4. Please describe which of the following performance measures is the most relevant to your firm's process of evaluating the financial performance of business line managers (tick ONLY one of the following):

- $\quad$ economic value-added $\left(\mathrm{EVA}^{\circledR}\right)$

- return on capital employed (ROCE)

- residual income

- embedded value

- other (please specify)

5. Please briefly comment below on the perceived decision-usefulness or otherwise of these alternative methods of performance measurement to both operational management and strategic management planning and control of your business. 